\title{
The Great Recession of 2007 in the United States and the male: female ratio at birth
}

\author{
Victor Grech \\ Department of Paediatrics, Mater Dei Hospital, Tal-Qroqq, Malta
}

\section{Abstract}

Objective: Male live births slightly exceed female live births by approximately $3 \%$. The ratio of male to total live births is conventionally represented as M/F. Many factors have been shown to affect M/F, mainly privation, toxins, and stress, all of which reduce M/F. Population stress may be engendered by natural phenomena such as earthquakes and man-made events such as short wars, terrorist attacks, and contracting economies. This study was conducted to ascertain whether the onset of the "Great Recession" (2007) was associated with changes in M/F in the United States (US). Material and Methods: Annual monthly live births by gender for January 2006 to December 2008 were obtained from United States Centres for Disease Control and Prevention.

Results: In 2007, there were 4316233 live births [M/F: 0.51157; 95\% confidence intervals: $0.51110-0.51205$ ). M/F rose between January and June, and then fell sharply between August and December. M/F was statistically significantly lower in the second half of 2007 ( $p=0.007$ ). The dip in $\mathrm{M} / \mathrm{F}$ from June to July was also significant $(\mathrm{p}=0.02)$. These findings were not replicated in the amalgamated data for 2006 and 2008.

Conclusion: The United States housing boom of the mid-2000s was fueled by rising house prices and cheap mortgages given to credit-poor buyers. A halt in rising house prices resulted in defaults and foreclosures, triggering the worst financial crisis since the Great Depression. The associated stress appears to have decreased M/F in the US. (J Turk Ger Gynecol Assoc 2015; 16: 70-3)

Keywords: United States, economic recession, birth rate/trends, infant, newborn, sex ratio

Received: 03 February, 2015

Accepted: 13 April, 2015

\section{Introduction}

Male live births slightly exceed female live births by a difference of approximately $3 \%$ (1). The ratio of male to total live births is conventionally (albeit technically erroneously) represented as $\mathrm{M} / \mathrm{F}$.

Many factors have been shown to affect $\mathrm{M} / \mathrm{F}$, and the principal factors include privation (2), toxins $(1,3)$, and stress (4), all of which tend to reduce $\mathrm{M} / \mathrm{F}$.

Population stress may be engendered through a variety of occurrences, including natural phenomena such as earthquakes (5), flooding, and the great London Smog (6). Manmade events have also been shown to reduce $\mathrm{M} / \mathrm{F}$, and these include short duration wars (7) and terrorist attacks (8).

The latter was famously shown after the September 11 attacks on the United States in 2001, where M/F dipped not only in New York(4) but also across the country in California (8). The M/F drop occurred 3-4 months after the event $(4,8)$ and was shown to be associated with an excess of male fetal losses (9). Contracting economies have also been shown to reduce $\mathrm{M} / \mathrm{F}$, as was witnessed in East Germany in 1991, the year following this country's reunification (10). However, not all studies are in agreement, with some failing to demonstrate significant $\mathrm{M} / \mathrm{F}$ reductions in response to parental stress (11).

The "Great Recession" is a term used to describe the worldwide economic decline that occurred at the end of this cen- tury's first decade. The International Monetary Fund stated that this was the worst global recession since the second world war (12-14).

The United States National Bureau of Economic Research has defined the recession as lasting 18 months, from December 2007 to June 2009. This was preceded by a subprime mortgage crisis wherein lenders who had offered home loans to individuals with poor credit lost these high-risk mortgages as the borrowers went into default $(13,14)$.

This study was conducted to ascertain whether these events were associated with changes in $\mathrm{M} / \mathrm{F}$.

\section{Material and Methods}

Annual monthly live births by gender between January 2006 and December 2008 were obtained from the website of the United States (US) Centers for Disease Control and Prevention (15). The amalgamation of monthly data for the two years adjacent to 2007, i.e., 2006 and 2008, were chosen for the purpose of comparison. Longer stretches were avoided as $\mathrm{M} / \mathrm{F}$ is known to undergo secular changes, which this study aimed to avoid (16). This comparison was made to gauge whether any changes in $\mathrm{M} / \mathrm{F}$ were greater than those normally expected by seasonality in $\mathrm{M} / \mathrm{F}$, which is known to rise in the US from February to June, followed by a drop in December $(17,18)$. Excel was used for data entry, overall analysis, and charting. 
Table 1. Male/Female comparisons for the United States in 2006, 2007, and 2008

\begin{tabular}{|c|c|c|c|c|c|c|c|c|c|}
\hline & 2006 & 2007 & 2008 & & Jul-Dec & 2006 & 2007 & 2008 & \\
\hline Male & 1634031 & 2208071 & 1644413 & & Male & 578860 & 1131438 & 571877 & \\
\hline Female & 1556227 & 2108162 & 1567747 & & Female & 551583 & 1082984 & 544805 & \\
\hline Total & 3190258 & 4316233 & 3212160 & & Total & 1130443 & 2214422 & 1116682 & \\
\hline $\mathrm{UCI}$ & 0.51274 & 0.51205 & 0.51248 & & UCI & 0.51299 & 0.51160 & 0.51305 & \\
\hline $\mathrm{M} / \mathrm{F}$ & 0.51219 & 0.51157 & 0.51193 & & $\mathrm{M} / \mathrm{F}$ & 0.51206 & 0.51094 & 0.51212 & \\
\hline LCI & 0.51165 & 0.51110 & 0.51139 & & LCI & 0.51114 & 0.51028 & 0.51119 & \\
\hline chi & & 2.8 & 1.0 & & chi & & 3.79 & 4.14 & \\
\hline $\mathrm{p}$ & & 1.0 & 0.3 & & $\mathrm{p}$ & & 0.052 & 0.042 & \\
\hline 2007 & Jan-Jun & Jul-Dec & Jul & Aug & $2006+2008$ & Jan-Jun & Jul-Dec & Jul & Aug \\
\hline Male & 1076633 & 1131438 & 194754 & 199240 & Male & 2127707 & 2229919 & 381128 & 389510 \\
\hline Female & 1025178 & 1082984 & 184862 & 191138 & Female & 2027586 & 2128037 & 362190 & 371621 \\
\hline Total & 2101811 & 2214422 & 379616 & 390378 & Total & 4155293 & 4357956 & 743318 & 761131 \\
\hline $\mathrm{UCI}$ & 0.5129 & 0.5116 & 0.5146 & 0.5119 & $\mathrm{UCI}$ & 0.51253 & 0.51216 & 0.51388 & 0.51288 \\
\hline $\mathrm{M} / \mathrm{F}$ & 0.5122 & 0.5109 & 0.5130 & 0.5104 & $\mathrm{M} / \mathrm{F}$ & 0.51205 & 0.51169 & 0.51274 & 0.51175 \\
\hline LCI & 0.5116 & 0.5103 & 0.5114 & 0.5088 & LCI & 0.51157 & 0.51122 & 0.51160 & 0.51063 \\
\hline chi & & 7.29 & & 5.42 & chi & & 1.09 & & 1.47 \\
\hline $\mathrm{p}$ & & 0.007 & & 0.020 & $\mathrm{p}$ & & 0.296 & & 0.226 \\
\hline$\%$ males & 51.22 & 51.09 & 51.30 & 51.04 & $\%$ males & 51.20 & 51.17 & 51.27 & 51.18 \\
\hline Difference & & 0.13 & & 0.27 & Difference & & 0.04 & & 0.10 \\
\hline 2006 & Jan-Jun & Jul-Dec & Jul & Aug & 2008 & Jan-Jun & Jul-Dec & Jul & Aug \\
\hline Male & 1055171 & 578860 & 188772 & 198576 & Male & 1072536 & 571877 & 192356 & 190934 \\
\hline Female & 1004644 & 551583 & 179162 & 189222 & Female & 1022942 & 544805 & 183028 & 182399 \\
\hline Total & 2059815 & 1130443 & 367934 & 387798 & Total & 2095478 & 1116682 & 375384 & 373333 \\
\hline UCI & 0.51295 & 0.51299 & 0.51468 & 0.51363 & UCI & 0.51251 & 0.51305 & 0.51402 & 0.51304 \\
\hline $\mathrm{M} / \mathrm{F}$ & 0.51226 & 0.51206 & 0.51306 & 0.51206 & $\mathrm{M} / \mathrm{F}$ & 0.51183 & 0.51212 & 0.51242 & 0.51143 \\
\hline $\mathrm{LCI}$ & 0.51158 & 0.51114 & 0.51144 & 0.51049 & LCI & 0.51116 & 0.51119 & 0.51082 & 0.50983 \\
\hline chi & & 0.12 & & 0.75 & chi & & 0.24 & & 0.74 \\
\hline $\mathrm{p}$ & & 0.732 & & 0.385 & $\mathrm{p}$ & & 0.623 & & 0.390 \\
\hline$\%$ males & 51.23 & 51.21 & 51.31 & 51.21 & $\%$ males & 51.18 & 51.21 & 51.24 & 51.14 \\
\hline Difference & & 0.02 & & 0.10 & Difference & & -0.03 & & 0.10 \\
\hline
\end{tabular}

The quadratic equations of Fleiss were used for exact calculation of 95\% confidence intervals for ratios (19). Chi tests and chi tests for trends for annual male and female births were used throughout using the Bio-Med-Stat Excel add-in for contingency tables (20). A p-value $\leq 0.05$ was taken to represent a statistically significant result. The analysis was of a large and anonymous dataset. Ethical approval was therefore not required. Informed consent was also not required for the same reason.

\section{Results}

This study analyzed 12829482 live births (6257104 males and 6572378 females) between 2006 and 2008. There was no statistically significant change in M/F between 2007 and the previous and following years (Table 1).
In 2007, there were a total of 4316233 live births with 2208071 males and 2108162 females (M/F $0.51157 ; 95 \%$ confidence intervals: $0.51110-0.51205)$. Monthly $\mathrm{M} / \mathrm{Fs}$ are shown in figure $1 \mathrm{M} / \mathrm{F}$ rose from January to June and then fell sharply from August to December.

$\mathrm{M} / \mathrm{F}$ was statistically significantly lower in the second half of 2007 when compared with that in the first half $(p=0.007$; Table 1). The dip in $\mathrm{M} / \mathrm{F}$ from July to August was also statistically significant $(p=0.02)$. The percentage changes in $M / F$ in 2007 are shown in Table 1, with a $0.13 \%$ decrease in male births from the first to the second halves of the year, and a 0.27 reduction between July and August; this occurred despite a rise in total births. For the amalgamation of 2006 and 2008 data, the declines were 0.04 and $0.10 \%$, respectively, and these declines were not statistically significant (Table 1 ). 


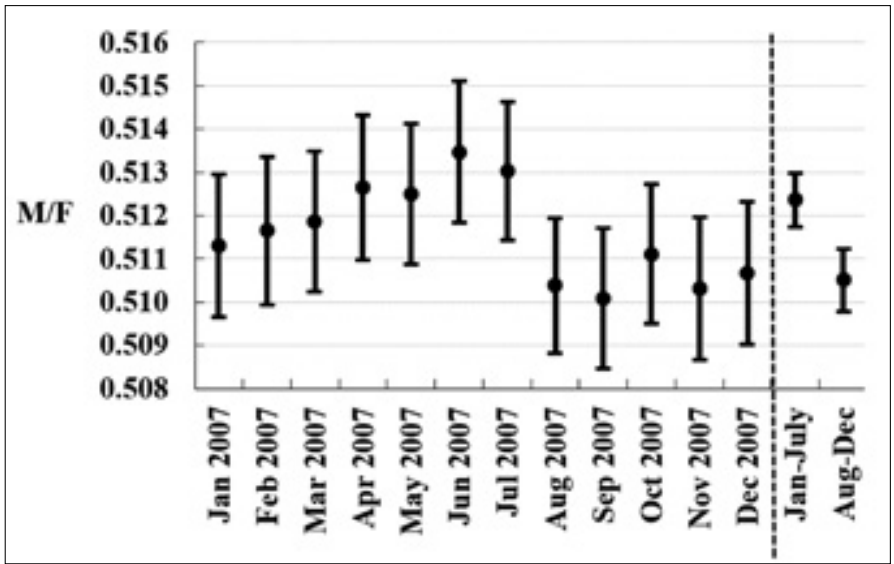

Figure 1. Monthly M/F for the United States in 2007 , as well as the first and second halves of 2007

$\mathrm{M} / \mathrm{F}$ was statistically significantly lower in the second half of 2007 when compared with that of the following year and was almost significantly lower when compared with that of the previous year (Figure 1).

\section{Discussion}

The United States housing boom of the mid-2000s was fueled by several factors. These were low mortgage interest rates, low short-term interest rates, relaxed standards for mortgage loans, and "irrational exuberance" (21). These factors prompted lenders to recklessly offer home loans to individuals with poor credit ratings, with the argument being that because house prices had not decreased nationwide since the Great Depression, then this trend would inevitably continue. Government regulators felt no need to attempt to control escalating home prices, not recognizing this as a bubble in the making (21).

In fact, the situation was such that mortgages would only continue to have interest rates if house prices kept rising, which was an unwarranted assumption. Furthermore, these mortgages were used to back securities, which would only continue to perform well if house prices continued to ascend. Furthermore, credit rating agencies continued to give AAA ratings to securities backed by subprime, but potentially adjustable, mortgage rates. This also encouraged foreign investors to heavily invest in these unreliable securities. All these factors made the housing bubble more extreme and fragile and the ensuing credit crisis more severe (21). When the real estate bubble burst, many borrowers were unable to make payments on their subprime mortgages and were unable to refinance them, resulting in defaults and foreclosures. This initiated the eventual cascade that continued as the "Great Recession," the worst financial crisis since the Great Depression $(13,14)$.

As a result of these influences, housing prices peaked in early 2006 and started to decline in late 2006 and 2007. The result was profound and affected not only the US economy but also international banks and the global economy. Warning signs commenced early in 2007. In February, the Hongkong and Shanghai Banking Corporation issued a warning of substantial losses in its mortgage arm because of subprime losses $(13,14)$.
The Federal Home Loan Mortgage Corporation (Freddie Mac, Fairfax County, Virginia), a public government-sponsored enterprise started tightening standards in February after a surge in subprime mortgage defaults publicly stating that it would stop entering into risky home loans $(13,14)$. In April, the subprime lender New Century Financial filed for bankruptcy with billions of dollars worth of bad loans, making over 3000 employees redundant and piling pressure on other US mortgages banks $(13,14)$.

In June 2007, Standard and Poor's and Moody's Investor Services downgraded over a 100 bonds backed by subprime mortgages. In the following month, Standard and Poor's placed 612 securities (backed by subprime mortgages) on a credit watch, and Countrywide Financial Corporation warned of upcoming difficult conditions. Bear Stearns also liquidated two hedge funds that invested in various mortgage-backed securities. Credit markets completely seized up in August when Banque Nationale de Paris, a large international bank, announced that two of its hedge funds were frozen $(13,14)$.

All this was associated with significant stress (22), leading to even suicides, not only in the US but also globally (23-25). Warning signs of the looming disaster emerged in February 2007, before spiraling out of control in August. This occurred four months after April, the midpoint between February and August.

While some studies failed to show a diminution in $\mathrm{M} / \mathrm{F}$ in response to parental stress (11), many other studies have shown that $\mathrm{M} / \mathrm{F}$ is acutely affected 3-4 months after such events, as evidenced in the United States after the September 11 attacks $(4,8)$ with an excess of male fetal losses (9). The disagreement between findings in different papers and peoples may stem from the fact that different populations may require not only different stimuli but also stimuli of different strengths to manifest statistically significant changes in $\mathrm{M} / \mathrm{F}$.

This accords with the Trivers-Willard hypothesis of parental investment, which proposes that natural selection has favored parents who bias M/F toward sons when in good condition and toward daughters when in poor condition (26). In this case, economic depression as a result of a contracting economy was the cause of substantial stress (22-26).

Contracting economies have also been shown to result in a drop in $\mathrm{M} / \mathrm{F}$, putatively for the same reasons. This was seen in East Germany after the region's reunification with West Germany. The ensuing economic turmoil in the first year after reunification was associated with a drop in $\mathrm{M} / \mathrm{F}$ in East Germany (10) where workers experienced the full effect of market forces and free competition, resulting in a $20 \%$ unemployment rate and another $20 \%$ reduced working days (27), factors that were attributed to have caused the decline (10).

Further evidence that stress reduces $\mathrm{M} / \mathrm{F}$ also comes from the observation that extrauterine pregnancies also result in a reduction in $\mathrm{M} / \mathrm{F}$ probably because of the hostile gestational environment (28).

The Great Recession induced significant stress worldwide; stress is known to reduce $\mathrm{M} / \mathrm{F}$. These factors may have been the cause of the M/F drop witnessed in the second half of 2007 in the United States. 
Ethics Committee Approval: N/A

Informed Consent: N/A

Peer-review: Externally peer-reviewed.

Conflict of Interest: No conflict of interest was declared by the authors.

Financial Disclosure: The authors declared that this study has received no financial support.

\section{References}

1. James WH. The human sex ratio. Part 1: A review of the literature. Hum Biol 1987; 59: 721-52.

2. Song $\mathrm{S}$. Does famine influence sex ratio at birth? Evidence from the 1959-1961 Great Leap Forward Famine in China. Proc Biol Sci 2012; 279: 2883-90. [CrossRef]

3. James WH. The human sex ratio. Part 2: A hypothesis and a program of research. Hum Biol 1987; 59: 873-900.

4. Catalano R, Bruckner T, Marks AR, Eskenazi B. Exogenous shocks to the human sex ratio: the case of September 11, 2001 in New York City. Hum Reprod 2006; 21: 3127-31. [CrossRef]

5. Fukuda M, Fukuda K, Shimizu T, Møller H. Decline in sex ratio at birth after Kobe earthquake. Hum Reprod 1998; 13: 2321-2. [CrossRef]

6. Lyster WR. Altered sex ratio after the London smog of 1952 and the Brisbane flood of 1965. J Obstet Gynaecol Br Commonw 1974; 81: 626-31. [CrossRef]

7. Zorn B, Sucur V, Stare J, Meden-Vrtovec H. Decline in sex ratio at birth after 10-day war in Slovenia: brief communication. Hum Reprod 2002; 17: 3173-7. [CrossRef]

8. Catalano R, Bruckner T, Gould J, Eskenazi B, Anderson E. Sex ratios in California following the terrorist attacks of September 11, 2001. Hum Reprod 2005; 20: 1221-7. [CrossRef]

9. Bruckner TA, Catalano R, Ahern J. Male fetal loss in the U.S. following the terrorist attacks of September 11, 2001. BMC Public Health 2010; 10: 273. [CrossRef]

10. Catalano RA. Sex ratios in the two Germanies: a test of the economic stress hypothesis. Hum Reprod 2003; 18: 1972-5. [CrossRef]

11. Khashan AS, Mortensen PB, McNamee R, Baker PN, Abel KM. Sex ratio at birth following prenatal maternal exposure to severe life events: a population-based cohort study. Hum Reprod 2009; 24: 1754-7. [CrossRef]

12. National Bureau of Economic Research. Business Cycle Dating Committee. Available from: http://www.nber.org/cycles/sept2010.html
13. Verick S, Islam I. The great recession of 2008-2009: causes, consequences and policy responses. Discussion paper series// Forschungsinstitut zur Zukunft der Arbeit 2010; 4934: 1-63.

14. Baldwin R. The great trade collapse: Causes, consequences and prospects. Geneva; Centre for Trade and Economic Integration: 2009.

15. Centers for Disease Control and Prevention. National Center for Health Statistics. Available from: http://www.cdc.gov/nchs/data access/vitalstats/VitalStats_Births.htm

16. Gini C. Sulla probabilita che termini di una serie erratica sieno tutti crescenti (o non decrescenti) ovvero tutti decrescenti (o non crescenti) con applicazioni ai rapporti dei sessi nascite umane in intervalli successivi e alle disposizioni dei sessi nelle fratellanze umane. Metron 1955; 17: 1-41.

17. Orwig GH. A statistical analysis of seasonal differences in human live birth sex ratios. Univ Chicago Masters Thesis 1948.

18. Slatis HM. Seasonal variation in the American live birth sex ratio. Am J Hum Genet 1953; 5: 21-33.

19. Fleiss JL. Statistical methods for rates and proportions. New York: John Wiley and Sons; 1981. p. 14-5.

20. Slezák P. Microsoft Excel add-in for the statistical analysis of contingency tables. Int J Innovation Educ Res 2014; 2: 90-100.

21. Holt J. A Summary of the Primary Causes of the Housing Bubble and the Resulting Credit Crisis: A Non-Technical Paper. Journal of Business Inquiry 2009; 8: 120-9.

22. Mulia N, Zemore SE, Murphy R, Liu H, Catalano R. Economic loss and alcohol consumption and problems during the 2008 to 2009 U.S. recession. Alcohol Clin Exp Res 2014; 38: 1026-34. [CrossRef]

23. Reeves A, McKee M, Gunnell D, Chang SS, Basu S, Barr B, Stuckler D. Economic shocks, resilience, and male suicides in the Great Recession: cross-national analysis of 20 EU countries. Eur J Public Health 2014.pii: cku168.

24. Phillips JA, Nugent CN. Suicide and the Great Recession of 20072009: the role of economic factors in the 50 U.S. states. Soc Sci Med 2014; 116: 22-31. [CrossRef]

25. Houle JN. Mental health in the foreclosure crisis. Soc Sci Med 2014; 118: 1-8. [CrossRef]

26. Trivers RL, Willard DE. Natural selection of parental ability to vary the sex ratio of offspring. Science 1973; 179: 90-2. [CrossRef]

27. Neumann M. German unification: Economic problems and consequences. Carnegie-Rochester Conference Series on Public Policy 1992; 36: 163-209. [CrossRef]

28. Masukume G. Live births resulting from advanced abdominal extrauterine pregnancy, a review of cases reported from 2008 to 2013. WebmedCentral Obstet Gynecol 2014; 5: WMC004510. 